\title{
Official Statistics in Spain: Current status and perspectives
}

\author{
Juan M. Rodriguez Poo \\ Instituto Nacional de Estadística
}

\section{Introduction}

This year Official Statistics commemorates the 75th anniversary of the creation of the National Statistics Institute (INE), which, at the same time, also coincides with the celebration of the 150th anniversary of the Geographical and Statistical Institute. This year also, our journal Estadística Española (REE), created already in 1958 is having a significant change: It will appear under a new name, Spanish Journal of Statistics (SJS), it will be published in English and a completely new Editorial Board has been appointed. In fact, the main aim of this renovation process is to continue the REE's work, although the international and global perspective of statistics will be strengthened, with a clear vocation to contribute to the development and better understanding of the official statistics through quality scientific articles. It will promote also the development and improvement of statistical methods, including statistical software and algorithms.

Official Statistics has undergone a formidable evolution throughout its long history (see Escribano Ródenas and Fernández Barberis (2009), Ray (2003) and García Villar and De Castro Puente (2011)), from its origins mainly based on extensive demographic accounts to the current state in which multiple statistics are produced, covering a large number of thematic areas. This evolution has been marked by the decisive contribution that the establishment of internationally harmonized methodologies has had, the development of statistical techniques, particularly those related to sampling theory (see Devaud and Tillé (2019)), as well as the wide implementation of information and communication technologies in the statistical production process. Nowadays, official statistics play a role of great relevance in our society, continuously offering comparable information of the highest quality that is then used in evidence-based decision-making processes. Thus, statistics constitutes a public good, available and accessible to all citizens in accordance with the principles contained in the code of good practice for European statistics.

The evolution that we observe in Official Statistics is perfectly reflected in the interests that have guided the INE since its creation and that are reflected in the first numbers of the REE. Thus we can find in these early years articles dedicated to Sampling Theory (see Azorín Poch (1959) and SánchezCrespo (1976)), Information Theory (see Arnaiz Vellando (1960)), Econometrics (see Pena Trapero (1960) and Pena Trapero (1974)), Monte Carlo techniques (see Diez de Artazcoz (1963)), Game Theory (see Ferrer Martín (1960)), or Statistical Decision Theory (see Neymann (1963)). Already in the early 
seventies we find papers devoted to statistics of extreme values (see Damas Rico (1972)), Bayesian Statistics (see Ibarrola Muñoz and Quesada Paloma (1972) and Quesada (1972)). These references and many others show how new statistical techniques have been progressively incorporated into Official Statistics. However, maintaining the current degree of relevance of the statistics requires a permanent renewal effort. Modernization of statistics is an inherent concern of national statistical offices, in areas that include the institutional environment and necessary resources, statistical production methods, data collection, dissemination and communication, or standards and metadata. The new challenges facing official statistics can be seen more clearly in the three specific cases presented below: globalization statistics; mobility statistics; and indicators of sustainable development.

\section{Globalization and Mobility Statistics and Sustainable Development Indicators}

Globalization represents one of the main challenges for business statistics. Given that statistics have been usually limited by national borders, the activities of groups of multinational companies such as the outsourcing of activities or foreign direct investment, clearly exceeds the traditional limits of performance of official statistics. In this context, it is necessary to coordinate a form of joint work with the rest of the member countries of the statistical community in order to produce economic indicators of globalization, and furthermore, to be able to assess the profile of multinationals, thus achieving an adequate measurement of this phenomenon. Access to administrative information by statistical authorities must be guaranteed, facilitating collaboration between administrations to prepare these statistics, respecting at all times the confidentiality of data and statistical secrecy.

A second case is the analysis of population mobility. This has been a phenomenon of great interest for the design of public policies at both municipal, regional, national and European levels. This phenomenon has usually been studied through population censuses or through specific surveys, which, although they offer high-value information, they have not provided so far a sufficient level of granularity and timeliness of their data. However, the use of big data in the statistical field as a new data source (see Galeano and Peña (2019)) allows new projects to be launched, such as the mobility study recently undertaken by the INE that offers results very detailed in a short space of time, always in aggregate, using percentages of people who leave their areas of residence towards other areas, thus enabling comparisons with the flows observed on a normal day.

A third case is made up of sustainable development indicators, which are, without doubt, the greatest challenge facing the world statistical system today. The production of indicators that covers the 17 objectives and 169 goals, together with their corresponding breakdowns, implies the availability of a wide set of data from base statistical operations and accounting systems that are subsequently presented jointly to offer an aggregate vision of the degree of compliance with the 2030 Agenda. Currently, almost half of the indicators have at least one series of data available, so that, once again, inter-institutional collaboration supported by the coordinating role of the INE is key to achieving complete all the information requested by the United Nations. 


\section{Conclusions}

The modernization process of official statistics has been parallel to the methodological evolution of statistical science. This is perfectly reflected in the topics dealt with by Estadistica Española since its creation in 1958. We are at a time when official statistics have to face very important challenges. Among them, perhaps the use of new data sources and the search for new forms of production are the most important. I trust that the new Spanish Journal of Statistics will collaborate in this task and be successful in its new phase.

\section{References}

Arnaiz Vellando, G. (1960). Information theory. Estadíst. Española No. 9, 5-29.

Azorín Poch, Francisco (1959). Sampling of finite populations. Systematic sampling. Estadíst. Española No. 5, 34-41 (1959).

Damas Rico, Pedro Manuel (1972). Introduction to the statistics of extreme values. Use in simulation methods. Estadíst. Española (57), 29-58.

Devaud, Denis and Yves Tillé (2019). Deville and Särndal's calibration: revisiting a 25-years-old successful optimization problem. TEST 28(4), 1033-1065.

Diez de Artazcoz, Vicente Jiménez (1963). The Monte Carlo method and its applications. Estadíst. Española No. 19, 12-30.

Escribano Ródenas, Ma. Carmen and Gabriela M. Fernández Barberis (2009). The beginnings of the official statistic in the Iberian Peninsula. Bol. Estad. Investig. Oper. 25(2), 129-139.

Ferrer Martín, Sebastián (1960). Theory of games. Estadíst. Española No. 6, 44-54.

Galeano, Pedro and Daniel Peña (2019). Data science, big data and statistics. TEST 28(2), 289-329.

García Villar, Jaume and Miguel Ángel De Castro Puente (2011). First World Statistics Day and the INE contribution to the achievements of official statistics in Spain. Bol. Estad. Investig. Oper. 27(1), 77-84.

Ibarrola Muñoz, Pilar and Vicente Quesada Paloma (1972). Neobayesian statistics. Estadíst. Española (56), 5-20.

Neymann, J. (1963). Two breakthroughs in the theory of statistical decision making. Estadíst. Española No. 18, 5-28.

Pena Trapero, Bernardo (1960). Econometric model for calculation and prediction of a total population subject to natural change and migration, by regions. Estadíst. Española No. 9, 47-61.

Pena Trapero, J. B. (1974). New specifications of multi-equation models: the fixed point and related estimation methods, and the iterative method of instrumental variables. Estadist. Española (64-65), $17-37$.

Quesada, Vicente (1972). Empirical Bayes methods applied to classification problems. Estadíst. Española (55), 13-22. 
Ray, S. (2003). Official statistics: past, present and future. Stat. Appl. (N.S.) 1(1-2), 1-12.

Sánchez-Crespo, J. L. (1976). A new sampling scheme: selection with graduated variable probabilities without replacement. Estadíst. Española (70-71), 5-12. 